\title{
Rekrutmen, Karakteristik Individual, dan Komitmen Organisasional terhadap Kinerja Karyawan
}

\section{Wildan Aditya Ramadhan', Trias Setyowati², Yohana Friskia Hia ${ }^{3}$, Tatit Diansari Reskiputri ${ }^{4}$} 1,2,3,4, Program Studi Manajemen Fakultas Ekonomi, Universitas Muhammadiyah Jember, Indonesia

\section{Keywords:}

Recruitment;

Characteristics;

Commitment;

Employee

Performance
Kata kunci:

Rekrutmen;

Karakteristik;

Komitmen;

Kinerja Karyawan

\section{ABSTRACT}

Abstract: The non-achievement of the production target that has an impact on the company's sales is caused by the lack of competence of employees regarding their work, individual characteristics and also low organizational commitment that affects employee performance. This study aims to analyze recruitment, individual characteristics, and organizational commitment to employee performance. The type of research used in this research is explanatory research. The population in this study amounted to 274 , while the sampling technique used proportional random sampling so that the sample consisted of 74 employees. In this study, the data analysis used was descriptive analysis and quantitative analysis. The results showed $p$-value $=0.01(<0.05)$ which means positive and significant, thus the first hypothesis which states that recruitment has a positive effect on employee performance. The $p$-value $=0.00(<0.05)$ which means it is positive, thus individual characteristics have a positive effect on employee performance. The $p$-value $=0.00(<0.05)$ which means it is positive, then organizational commitment has a positive effect on employee performance. $F$ value $=23,699$ is positive with $p$-value $=0.000(<0.05)$ which means significant, thus recruitment, individual characteristics, organizational commitment simultaneously (together) have a positive effect on employee performance. The implications of this research are expected to make the company even better in carrying out the goals of the company's vision and mission.

Abstrak: Ketidaktercapaian target produksi yang berdampak terhadap penjualan perusahaan ini disebabkan oleh kompetensi karyawan yang masih kurang tentang pekerjaannya, karakteristik individu, dan juga komitmen organisasi yang dimiliki oleh karyawan masih rendah. Hal ini memengaruhi kinerja karyawan. Penelitian ini bertujuan untuk menganalisis rekrutmen, karakteristik individu, dan komitmen organisasional terhadap kinerja karyawan. Jenis penelitian yang digunakan dalam penelitian ini adalah explanatory research. Populasi dalam peneitian ini berjumlah 274 , sedangkan teknik pengambilan sampel menggunakan proportional random sampling, sehingga sampel berjumlah 74 karyawan. Analisis data yang digunakan adalah analisis deskriptif dan analisis kuantitatif. Hasil penelitian menunjukkan p-value $=0,01(<0,05)$ yang artinya positif dan signifikan. Dengan demikian rekrutmen berpengaruh positif terhadap kinerja karyawan. Nilai $p$-value $=0,00(<0,05)$ yang artinya positif. Dengan demikian, karakteristik individual berpengaruh positif terhadap kinerja karyawan. Nilai $p$-value $=0,00(<0,05)$ yang artinya positif, maka komitmen organisasional berpengaruh positif terhadap kinerja karyawan. Nilai $F=23,699$ bernilai positif dengan $p$-value $=0,000(<0,05)$ yang berarti signifikan. Dengan demikian rekrutmen, karakteristik individual, komitmen organisasional secara simultan (bersama-sama) berpengaruh positif terhadap kinerja karyawan. Implikasi penelitian ini diharapkan dapat menjadikan perusahaan lebih baik lagi dalam melaksanakan tujuan visi misi perusahaan.

Alamat Korespondensi:

E-mail: ramadhan89@gmail.com (Ramadhan)

$\begin{array}{ll}\text { History: } & \\ \text { Received } & \text { : 01 Juni } 2021 \\ \text { Revised } & \text { : 04 Juni } 2021 \\ \text { Accepted } & \text { : 09 Juli } 2021 \\ \text { Published } & \text { : 25 Juli } 2021\end{array}$

History:

Received : 01 Juni 2021

Accepted : 09 Juli 2021
Publisher: Undiksha Press

Licensed: This work is licensed under a Creative Commons Attribution 3.0 License






\section{Pendahuluan}

Pada era globalisasi di tengah perkembangan teknologi dan ilmu pengetahuan seperti ini, perusahaan dituntut mampu mengelola sumber daya manusia yang handal dan berkualitas, sehingga terwujudnya tujuan perusahaan. Oleh karena itu, peranan sumber daya manusia dalam perusahaan sangatlah penting guna menunjang aktivitas, keberlangsungan dan keberhasilan suatu perusahaan (Mangkunegara, 2013; Rangga \& Naomi, 2017). Tidak dapat dipungkiri keberadaan sumber daya manusia yang handal memiliki peran yang lebih strategis dibandingkan dengan sumber daya lain (Hindriari, 2018; Rafiditya \& Syarifuddin, 2020). Salah satu hal yang terpenting dalam kegiatan aktivitas sumber daya manusia adalah mengenai rekrutmen karyawan (Hindriari, 2018; Pratisardy \& Lukito, 2019). Rekrutmen merupakan serangkaian aktivitas untuk mencari dan memikat pelamar kerja dengan motivasi, kemampuan, keahlian, dan pengetahuan yang diperlukan guna menutupi kekurangan yang diidentifikasi dalam perencanaan kepegawaian. Untuk itu, kegiatan proses rekrutmen merupakan hal yang sangat penting dalam sebuah perusahaan. Tingkat keakuratan dalam aktivitas rekrutmen dapat meningkatkan efektivitas dan efisiensi operasional perusahaan untuk mengoptimalkan pencapaian tujuan utamanya yaitu perolehan laba usaha.

Namun kenyataannya, permasalahan yang terjadi yaitu kinerja beberapa perusahaan menurun (Cesilia et al., 2018; Hermawan, 2018). CV Gagak Hitam Bondowoso merupakan perusahaan yang bergerak di bidang industri rokok yang berdiri sejak tahun 2004. CV Gagak Hitam Bondowoso terletak di wilayah kabupaten Bondowoso yang didirikan oleh bapak Nawar H. Wasil. Awalnya, pendirinya merupakan pembisnis penyuplai tembakau ke perusahaan rokok di Indonesia. CV. Gagak Hitam Bondowoso bertujuan untuk mencapai keuntungan yang tinggi namun kinerja yang dihasilkan oleh karyawan tidak sesuai dengan yang diharapkan. Kinerja yang rendah diduga karena rekrutmen yang tidak sesuai dengan bidangnya serta karakterisitik individu yang berbeda dan juga komitmen organisasi yang dimiliki karyawan rendah. Kinerja CV. Gagak Hitam Bondowoso mengalami penurunan setiap tahunnya yang tidak mencapai target. Hal tersebut dapat terlihat pada realisasi produksi rokok yang terjadi serta berdampak terhadap target penjualan yang mengalami penurunan yang sudah ditetapkan. Hal ini dapat terlihat dari pencapaian penjualan perusahaan yang tergolong masih sering tidak mencapai target penjualan. Hal ini akan berdampak pada kelangsungan hidup perusahaan. Ketidaktercapaian target produksi yang berdampak terhadap penjualan perusahaan ini disebabkan oleh kompetensi karyawan yang masih kurang di bidang pekerjaannya, karakteristik individu, dan juga komitmen organisasi yang dimiliki oleh karyawan masih rendah sehingga mempengaruhi kinerja karyawan.

Tabel 1. Rekapitulasi Laporan Produksi Rokok CV Gagak Hitam Bondowoso

\begin{tabular}{lccc}
\hline Tahun & Target Produksi (Batang) & Realisasi Produksi (Batang) & Ketercapaian Target \\
\hline 2016 & 25.000 .000 & 24.000 .000 & $96 \%$ \\
2017 & 25.000 .000 & 22.500 .000 & $90 \%$ \\
2018 & 25.000 .000 & 21.750 .000 & $87 \%$ \\
2019 & 25.000 .000 & 20.750 .000 & $83 \%$ \\
2020 & 25.000 .000 & 20.250 .000 & $81 \%$ \\
\hline
\end{tabular}

Tabel tersebut menunjukkan bahwa angka cenderung mengalami penurunan jumlah produksi yang berdampak kepada kinerja karyawan. Hal ini terlihat pada persentase ketercapaian target produksi 5 tahun terakhir yang mengalami penurunan. Fenomena kompetensi yang terdapat di CV Gagak Hitam Bondowoso terdapatnya karyawan yang direkrut tidak berdasarkan kriteria yang ditentukan oleh perusahaan. Hal ini membuat kinerja karyawan yang dihasilkan kurang maksimal. Masih banyaknya karyawan yant diterima tidak sesuai dengan kriteria yang diinginkan perusahaan, sehingga kinerja karyawan mengalami penurunan. CV Gagak Hitam Bondowoso memiliki visi dan misi yang ingin dicapai. Agar visi dan misi dapat tercapai diperlukan adanya target kerja untuk seluruh karyawan. Target kerja tersebut dapat dijalankan jika adanya karakteristik individual dan komitmen 
terhadap organisasi pada diri setiap karyawan. Masih banyak karyawan yang tidak mengalami kenaikkan gaji. Penyebabnya adalah masih seringnya karyawan terlambat hadir, kesalahan yang cukup fatal, karyawan kurang mampu menyesuaikan diri dengan pekerjaannya, dan juga karyawan lebih mementingkan urusan pribadi dibandingkan dengan pekerjaannya. Hal tersebut dapat mengakibatkan menurunnya kinerja karyawan karena gaji mereka tidak mengalami peningkatan dan juga karyawan akan mengundurkan diri dari perusahaan atau keluar dari perusahaan.

Tabel 2. Data Karyawan CV Gagak Hitam Bondowoso 2016-2020

\begin{tabular}{cc}
\hline Tahun & Jumlah Karyawan \\
\hline 2016 & 387 \\
2017 & 349 \\
2018 & 304 \\
2019 & 260 \\
2020 & 274 \\
\hline
\end{tabular}

Sumber: Bagian Personalia CV. Gagak Hitam Bondowoso

Dari data di atas diketahui terdapat penurunan jumlah karyawan setiap tahunnya. Data tersebut menunjukkan bahwa tiap tahun terjadi penurunan jumlah karyawan yang berakibat menurunnya jumlah produksi yang dihasilkan CV. Gagak Hitam Bondowoso pada tahun 2020. Fenomena ini juga memengaruhi keberlangsungan organisasi agar lebih maju sesuai visi dan misi perusahaan. Untuk itu, manajer personalia memerlukan rekrutmen yang ketat untuk menumbuhkan semangat komitmen organisasi dan karakteristik individu karyawan agar perusahaan berjalan sesuai dengan visi misi yang dibuat oleh CV. Gagak Hitam Bondowoso. Dengan demikian, karyawan yang dihasilkan memiliki keahlian yang dibutuhkan dan tidak terjadinya pengurangan karyawan yang dianggap kurang sesuai spesifikasi yang dibutuhkan.

Rekrutmen terhadap karyawan sangat membantu perusahaan untuk dapat mencapai kinerja baik bagi perusahaan itu sendiri maupun bagi karyawan yang ada dalam perusahaan itu (Hindriari, 2018; Syatoto, 2018). Kinerja digambarkan sebagai hasil kerja secara kualitas dan kuantitas yang dicapai oleh seorang karyawan dalam melaksanakan tugasnya sesuai dengan tanggung jawab yang diberikan kepadanya (Hindriari, 2018; Rafiditya \& Syarifuddin, 2020). Yang terjadi adalah pelamar hanya orang-orang tertentu, sehingga lamaran yang masuk tidak banyak. Dengan demikian, akan sulit memperoleh karyawan yang baik (Pratisardy \& Lukito, 2019; Syatoto, 2018). Metode terbuka yaitu pelaksanaan rekrutmen yang diumumkan melalui iklan di media massa. Hal ini dilakukan untuk mendapatkan banyak lamaran yang masuk, sehingga kesempatan memperoleh karyawan yang baik dan handal menjadi lebih besar dan nantinya memiliki karyawan yang berkinerja baik pula (Andayati \& Meidasari, 2018; Lina, 2020; Ni Made Widnyani, 2020). Perencanaan sumber daya manusia dalam suatu perusahaan bertujuan untuk meningkatkan kinerja karyawan demi terlaksananya tujuan perusahaan. Salah satu perencanaan tersebut adalah mempersiapkan sumber daya manusia, menggali potensi diri dengan merekrut dan menyeleksi karyawan yang akan diterima dalam suatu perusahaan, dan melakukan pelatihan terhadap karyawan yang baru ataupun karyawan yang lama. Tenaga kerja yang bekerja sesuai dengan fungsinya (the right man in the right place) akan menunjang tercapainya keberhasilan tujuan perusahaan.

Karakteristik individu adalah minat, sikap terhadap diri sendiri, pekerjaan, dan situasi pekerjaan, kebutuhan individual, kemampuan atau kompentensi, pengetahuan tentang pekerjaan dan emosi, suasana hati, perasaan keyakinan dan nilai-nilai (Kridharta \& Rusdianti, 2017; Triasmoko \& Mukzam, 2014). Karakteristik individu adalah individu seutuhnya (the whole person) memiliki kebutuhan fisiologis yang sama, tetapi tidak akan sama dalam memenuhi kebutuhan psikologis, disebabkan oleh latar belakang yang berbeda-beda (kognitif, afektif, serta psikomotorik). Berlandaskan ilmu perilaku, setiap individu memiliki keragaman dalam skala sikap dan perilaku (individual behavior), yang di dalamnya terdapat beberapa variabel yang menggambarkan perbedaan itu, antara lain kemampuan dan kepribadian. (Tampubolon, 2008:27) Selain itu untuk mendukung 
kinerja yang baik dari setiap karyawan, perusahaan berusaha untuk mengarahkan para karyawannya untuk dapat mencapai tujuan perusahaan yang telah ditentukan. Untuk mencapai tujuan organisasi, dibutuhkan komitmen dari setiap karyawan terhadap perusahaan. Komitmen yang ditunjukan dari sikap karyawan dalam bekerja untuk kemajuan perusahaan. Memiliki karyawan dengan komitmen yang tinggi terhadap perusahaan pastilah harapan setiap perusahaan (Jainuddin, 2020; Kridharta \& Rusdianti, 2017). Karyawan yang demikian diharapkan bisa ikut memajukan perusahaan, sehingga tujuan-tujuan yang ingin dicapai perusahaan bisa terwujud. Komitmen pada setiap karyawan sangat penting karena dengan suatu komitmen seorang karyawan dapat menjadi lebih bertanggung jawab terhadap pekerjaannya dibanding dengan karyawan yang tidak memiliki komitmen (Kridharta \& Rusdianti, 2017; Lengkong, 2018).

Penelitian yang sejalan terkait rekrutmen, karakteristik individu dan komitmen terhadap kinerja. Rekrutmen memberikan pengaruh yang positif terhadap kinerja karyawan. Rekrumen yang baik akan memperoleh karyawan yang berkualitas (Hindriari, 2018; Pratisardy \& Lukito, 2019; Syatoto, 2018). Selain itu, komitmen juga memberikan dampak terhadap kinerja karyawan (Lengkong, 2018; Lestri, 2020). Kinerja karyawan sangat memengaruh pencapaian tujuan perusahaan. Komitmen yang baik akan memiliki kinerja yang baik juga. Tujuan penelitian ini untuk menganalisis rekrutment karyawan, karakteristik individual, dan komitment organisasi terhadap kinerja karyawan. Adanya penelitian ini diharapkan dapat menjadikan perusahaan lebih baik lagi dalam melaksanakan tujuan visi misi perusahaan.

\section{Metode}

Jenis penelitian yang digunakan dalam penelitian ini adalah explanatory research. Penelitian yang dilaksanakan adalah penelitian kausal. Jenis penelitian adalah penelitian kuantitatif dengan mencari hubungan kausal. Hubungan kausal merupakan hubungan yang bersifat sebab akibat. Jadi ada variabel independen (variabel yang mempengaruhi) dan variabel dependen (variabel yang dipengaruhi). Penelitian explanatory untuk menguji hipotesis yang akan dilakukan, antara satu variabel dengan variabel lain dapat diuji pengaruhnya satu sama lain. Populasi dalam peneitian ini berjumlah 274 , sedangkan teknik pengambilan sampel menggunakan proportional random sampling sehingga sampel berjumlah 74 karyawan CV Gagak Hitam Bondowoso.

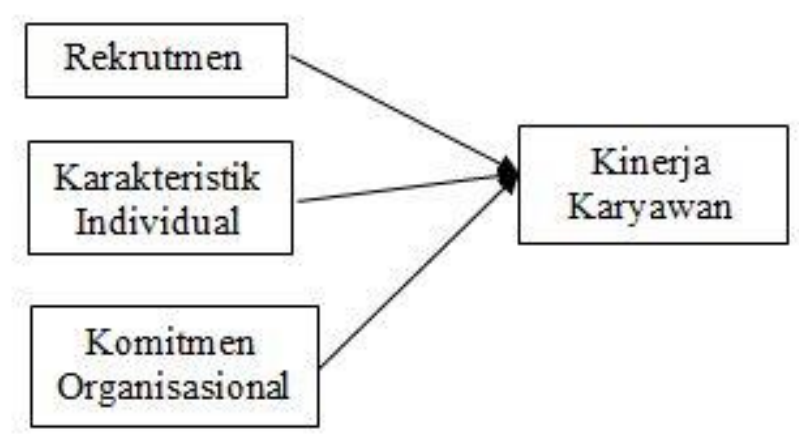

Gambar 1. Desain Penelitian

Berdasarkan jenis data dan analisisnya, penelitian ini termasuk ke dalam jenis penelitian dengan metode kuantitatif. Analisis data yang digunakan adalah analisis deskriptif dan analisis kuantitatif. Analisis deskriptif adalah penyajian data melalui tabel deskriptif dan frekuensi. Penghitungan penyebaran data melalui perhitungan rata-rata standar deviasi dan penghitungan persentase. Ukuran pendiskripsian adalah dengan pemberian angka, baik dalam jumlah maupun persentase. Analisis regresi linier berganda digunakan untuk menguji hipotesis 1,2,3 dan hipotesis 4 . hipotesis 1,2,3 diuji menggunakan uji t. sedangkan hipotesis 4 menggunakan uji $\mathrm{f}$. 


\section{Hasil dan Pembahasan}

\section{Hasil Penelitian}

Hasil penelitian yang bertujuan menganalisis rekrutmen, karakteristik individual, dan komitmen organisasional terhadap kinerja karyawan. Hasil penelitian yang berkaitan dengan rekrutmen, karakteristik individual ,dan komitmen organisasi terhadap kinerja karyawan disajikan berikut ini.

Tabel 1. Analisis Regresi Liniear Berganda

\begin{tabular}{|c|c|c|c|c|c|c|}
\hline \multicolumn{7}{|c|}{ Coefficients } \\
\hline \multirow{2}{*}{\multicolumn{2}{|c|}{ Model }} & \multicolumn{2}{|c|}{$\begin{array}{l}\text { Unstandardized } \\
\text { Coefficients }\end{array}$} & \multirow{2}{*}{$\begin{array}{c}\begin{array}{c}\text { Standardized } \\
\text { Coefficients }\end{array} \\
\text { Beta }\end{array}$} & \multirow[b]{2}{*}{$\mathrm{t}$} & \multirow[b]{2}{*}{ Sig. } \\
\hline & & $B$ & Std. Error & & & \\
\hline & (Constant) & 22,22 & 3,48 & & 6,38 & 0,00 \\
\hline & Rekrutmen & 0,56 & 0,20 & 0,31 & 2,76 & 0,01 \\
\hline & Karkteristik & 0,68 & 0,22 & 0,35 & 3,13 & 0,00 \\
\hline & Komitmen & 0,49 & 0,07 & 0,70 & 6,89 & 0,00 \\
\hline
\end{tabular}

Berdasarkan tabel 1 hasil dari coefficients dapat dikembangkan dengan menggunakan model persamaan regresi linier berganda. Konstanta sebesar 22,22, artinya jika tidak ada proses rekrutmen, karakteristik individual, dan komitmen organisasional, maka kinerja tetap 22,22. Koefisien Regresi X1 sebesar 0,56, artinya setiap kenaikan satu satuan Rekrutmen akan meningkatkan tingkat Kinerja sebesar 0,56 begitu sebaliknya. Setiap penurunan satu satuan Rekrutmen akan menurunkan tingkat Kinerja sebesar 0,56, dengan anggapan bahwa X2 tetap. Koefisien Regresi X2 sebesar 0,68, artinya setiap kenaikan satu satuan karakteristik individual akan meningkatkan kinerja sebesar sebesar 0,68 begitu sebaliknya setiap penurunan satu satuan karakteristik individual akan menurunkan kinerja sebesar 0,68 dengan anggapan bahwa X3 tetap. Koefisien Regresi X3 sebesar 0,49, artinya setiap kenaikan satu satuan komitmen organisasional akan meningkatkan kinerja sebesar 0,49 begitu sebaliknya setiap penurunan satu satuan komitmen organisasional akan menurunkan kinerja sebesar 0,49 dengan anggapan bahwa X1 tetap. Tanda (+) menunjukkan arah hubungan yang searah, sedangkan tanda (-) menunjukkan arah hubungan yang berbanding terbalik antar variabel independen $(X)$ dan variabel dependen $Y$. Koefisien determinasi memiliki fungsi untuk mengetahui besarnya variasi variabel independen dalam menerangkan variabel dependen atau untuk menjelaskan sejauh mana kemampuan variabel independen (rekrutmen, karakteristik individual, dan komitmen organisasi) terhadap variabel dependen (kinerja karywan). Dari hasil pengujian dengan menggunakan SPSS 22 diperoleh nilai koefisien determinasi pada tabel 2 .

Tabel 2. Hasil Uji Koefisien Determinasi

\begin{tabular}{lllll}
\hline Model Summary & & & \\
\hline Model & $\mathbf{R}$ & R Square & Adjusted R Square & $\begin{array}{l}\text { Std. Error of the } \\
\text { Estimate }\end{array}$ \\
\hline 1 & 0,72 & 0,51 & 0,49 & 0,87 \\
\hline
\end{tabular}

Hasil penghitungan $R$ Square $\left(R^{2}\right)$ menunjukkan nilai sebesar 0,51 , artinya sebesar $51,00 \%$ variabel Rekrutmen (X1), Karakteristik Individual (X2), dan Komitmen Organisasi (X3) mampu menjelaskan naik turunnya kinerja karyawan CV Gagak Hitam Bondowoso (Y), sedangkan sisanya $49,00 \%$ dipengaruhi oleh variabel lain yang tidak terdapat dalam penelitian. 


\section{Pembahasan}

Hasil penelitian yang berkaitan dengan rekrutmen, karakteristik individual. dan komitmen organisasional terhadap kinerja karyawan CV Gagak Hitam Bondowoso adalah sebagai berikut. Temuan pertama menunjukkan bahwa diketahui $p$-value $=0,01(<0,05)$, yang artinya positif dan signifikan. Dengan demikian hipotesis pertama yang menyatakan rekrutmen berpengaruh positif terhadap kinerja karyawan. Temuan ini diperkuat olen penelitian sebelumnya menyatakan bahwa rekrutmen berpengaruh positif, tetapi tidak signifikan terhadap kinerja karyawan (Pratisardy \& Lukito, 2019). Selain itu, rekrutmen berpengaruh positif, tetapi tidak signifikan terhadap kinerja karyawan (Aziz et al., 2017; Efendi \& Winenriandhika, 2021; Syatoto, 2018). Hal ini menunjukkan bahwa rekrutmen merupakan salah satu penentu terjadinya kinerja karyawan yang baik jika rekrutmen yang dilakukan oleh perusahaan dilakukan sesuai prosedur akan menciptakan kinerja pada karyawan (Andayati \& Meidasari, 2018; Aziz et al., 2017; Ni Made Widnyani, 2020).

Rekrutmen yang dilakukan CV Gagak Hitam Bondowoso sudah sesuai dengan ketentuan peraturan menetri tenaga kerja terkait dengan upaya mewujudkan penghasilan yang layak bagi pekerja perlu ditetapkan upah minimum dengan mempertimbangkan peningkatan kesejahteraan pekerja tanpa mengabaikan peningkatan produktivitas. Selain itu, perusahaan juga menetapkan kualifikasi pelamar dengan kriteria tertentu, misalnya pelamar harus mempunyai pengalaman kerja yang sesuai dengan posisi pekerjaan yang dikehendaki. Di samping itu, jika perusahaan ingin menambah dan membutuhkan, maka pihak pimpinan akan mengeluarkan pengumuman untuk merekrut calon karyawan. Namun, CV Gagak Hitam Bondowoso juga memiliki tanggung jawab sosial dan memberikan kesempatan kepada masyarakat setempat untuk menjadi calon tenaga kerja di perusahaan itu. Dalam pelaksanaan tanggung jawab terhadap karyawan, perusahaan mengikuti peraturan dan perundang- undangan negara, misalnya gaji atau upah keluarga sesuai dengan UMR (upah minimum regional) serta memberika asuransi kepada para karyawan karena hal tersebut sebagai suatu cara dapat menaikkan kinerja karyawan.

Temuan kedua, pengaruh karakteristik individual terhadap kinerja karyawan CV Gagak Hitam Bondowoso. Hasil menunjukkan bahwa p-value $=0,00(<0,05)$ yang artinya positi. Dengan demikian, hipotesis kedua yang menyatakan karakteristik individual berpengaruh positif terhadap kinerja karyawan. Temuan ini diperkuat oleh hasil penelitian sebelumnya menyatakan bahwa karakteristik individu berpengaruh signifikan terhadap kinerja karyawan (Hidayat \& Cavorina, 2018; Kridharta \& Rusdianti, 2017). Karakteristik individu berpengaruh positif dan signifikan terhadap kinerja karyawan. Hal ini menunjukkan bahwa karakteristik individual merupakan salah satu penentu terjadinya kinerja karyawan yang baik. Karakteristik pegawai berpengaruh kuat dan signifkan terhadap kinerja pegawai (Kridharta \& Rusdianti, 2017). Dapat dijelaskan bahwa karakteristik individual yaitu karyawan harusnya mampu melaksanakan tugas tanpa menunggu intruksi dari atasan, memahami peraturan tertulis dari atasan sesuai maksud yang diinginkan, serta karyawan harus selalu datang tepat waktu ke tempat kerja. Semua itu dapat memengaruhi kinerja karyawan, misalnya jika karyawan yang datangnya terlambat, maka terjadinya penurunan kinerja karyawan. Hal ini berdampak kepada kebiasaann yang buruk apabila perusahaan tidak memberikan sanksi kepada karyawan yang tidak tepat waktu. Di samping itu, karyawan juga harus teliti, memahami tugas yang menjadi tanggung jawabnya, dan mampu memahami setiap perintah atasan secara lisan. Pegawai yang memiliki karakteristik yang mendukung pencapaian kinerja yang tinggi dengan memiliki kemampuan pada bidangnya masing-masing serta mempunyai sikap dan nilai yang baik akan berpengaruh terhadap peningkatan kemajuan perusahaan. Karakteristik individu merupakan sikap karyawan yang tidak mengeluh saat medapatkan tugas dari atasan meliputi seberapa tinggi kecintaan pegawai pada bidang pekejaan yang dijalaninya. Nilai meliputi tipe pegawai yang pekerja keras serta jujur dalam menjalankan tugas dari perusahaan. Pendidikan meliputi cara berpikir tentang cara penyelesaian tugas serta pengetahuan dan keterampilan di bidang pekerjaan yang dijalani. Usia meliputi kematangah berpikir serta pengalaman kerja seorang pegawai. Hal ini yang dapat mendukung peningkatan kinerja karyawan (Pratiwi et al., 2021).

Temuan ketiga, pengaruh komitmen organisasional terhadap kinerja karyawan CV Gagak Hitam Bondowoso. Hasil menunjukkan bahwa p-value $=0,00(<0,05)$ yang artinya positif, maka 
komitmen organisasional berpengaruh positif terhadap kinerja karyawan. Temuan ini diperkuat oleh penelitian yang menyatakan komitmen organisasi memengaruhi secara positif terhadap kinerja karyawan (Kridharta \& Rusdianti, 2017; Lengkong, 2018; Lestri, 2020). Maka dapat di jelaskan bahwa faktor komitmen organisasional yaitu karyawan memahami dan yakin dengan visi misi dan tujuan perusahaan serta selalu menaati norma-norma yang diterapkan dalam perusahaan dan mematuhi peraturan dan kebijakan yang berlaku di perusahaan (Lestri, 2020; Octoriawan \& Rusliati, 2019). Karyawan siap mengerjakan tugas yang diberikan perusahaan. Hal tersebut akan meningkatkan kinerja. Apabila karyawan mempriotaskan kepentingan perusahaan di atas kepentingan karyawan, karyawan juga harus menggunakan peralatan perusahaan dengan baik dan benar sesuai dengan SOP agar tidak terjadi kerusakan. Jika hal tersebut terjadi maka akan memengaruhi kinerja karyawan serta karyawan akan merasa rugi. Karyawan yang memiliki komitmen yang tinggi akan berdampak kepada kemajuan perusahaan karena mendapatkan keuntungan lebih dari perusahaan jika tetap tinggal pada perusahaan dibandingkan harus pindah ke tempat pekerjaan yang lain (Wibowo, 2017; Wolomasi et al., 2019). Karyawan yang memiliki komitmen yang tinggi tidak akan meninggalkan perusahaan walaupun menerima tawaran pekerjaan yang lebih baik.

Temuan keempat, pengaruh rekrutmen, karakteristik individual, dan komitmen organisasional terhadap kinerja karyawan CV Gagak Hitam Bondowoso. Hasil menunjukkan bahwa nilai $F=23,699$ bernilai positif dengan $p$-value $=0,000(<0,05)$ yang berarti signifikan, dengan demikian hipotesis keempat yang berbunyi rekrutmen, karakteristik individual, komitmen organisasional secara simultan (bersama-sama) berpengaruh positif terhadap kinerja karyawan. Rekrutmen dan komitmen organisasi dapat berpengaruh positif terhadap kinerja karyawan (Andayati \& Meidasari, 2018; Efendi \& Winenriandhika, 2021).

\section{Simpulan}

Rekrutmen berpengaruh terhadap kinerja karyawan CV Gagak Hitam Bondowoso. Hal ini terbukti bahwa variable komitmen organisasional berpengaruh terhadap kinerja karyawan CV Gagak Hitam Bondowoso. Rekrutmen, karakteristik individual, dan komitmen organisasional bersama-sama berpengaruh terhadap kinerja karyawan CV Gagak Hitam Bondowoso. Keterbatasan penelitian ini hanya dilakukan pada satu perusahaan. Implikasi dalam penelitian ini diharapkan pihak manajemen perusahaan CV Gagak Hitam Bondowoso memperhatikan proses rekrutmen, karakteristik individual karyawan, serta komitmen organisasional untuk meningkatkan kinerja.

\section{Daftar Pustaka}

Andayati, T. N., \& Meidasari, E. (2018). Pengaruh Sistem Rekrutmen dan Pemberian Kompensasi terhadap Kinerja Karyawan Sukarela (TKS) Rumah Sakit Abdul Moloek Provinsi Lampung. Jurnal Ekonomi Dan Bisnis, 5(1), 55 - 69. https://doi.org/10.35590/jeb.v5i1.684.

Aziz, T. A., Maarif, M. S., \& Anggraini Sukmawati. (2017). Pengaruh Rekrutmen dan Seleksi terhadap Kinerja. Jurnal Aplikasi Bisnis Dan Manajemen (JABM), 3(2), 246. https://doi.org/10.17358/jabm.3.2.246.

Cesilia, K. A., Tewal, B., \& Tulung, J. E. (2018). Pengaruh Disiplin Kerja, Perencanaan Karier, dan Kompetensi terhadap Kinerja Karyawan Kantor Pelayanan Pajak (KPP) Pratama Manado. Jurnal EMBA: Jurnal Riset Ekonomi, Manajemen, Bisnis Dan Akuntansi, 6(1), 426-434. https://doi.org/10.35794/emba.v6i1.19153.

Efendi, S., \& Winenriandhika, O. (2021). Pengaruh Rekrutmen, Pelatihan, dan Pengalaman Kerja terhadap Kepuasan Kerja dan Dampaknya pada Kinerja Karyawan di PT Marketama Indah. Jurnal IImiah Nasional, 3(1), 99-110. https://doi.org/10.110915/jin.v3i1.383.

Hermawan, H. (2018). Analisis Pengaruh Bauran Pemasaran terhadap Keputusan, Kepuasan, dan Loyalitas Konsumen dalam Pembelian Roti Ceria Di Jember. Jurnal Manajemen dan Bisnis Indonesia, 3(2), 1-15. https://doi.org/10.17509/jaset.v3i2.8918. 
Hidayat, R., \& Cavorina, A. (2018). Pengaruh Karakteristik Individu dan Lingkungan Kerja terhadap Kinerja Karyawan PT Ladtek Bi Metal Manufacturing. Journal Of Applied Business Administration, 1(2), 337-347. https://doi.org/10.30871/jaba.v1i2.617.

Hindriari, R. (2018). Pengaruh Rekrutmen dan Seleksi terhadap Kinerja Karyawan pada PT Boga Lestari Sentosa. JENIUS (Jurnal Ilmiah Manajemen Sumber Daya Manusia), 2(1). https://doi.org/10.32493/JJSDM.v2i1.1934.

Jainuddin. (2020). Pengaruh Budaya Organisasi, Komitmen Guru dan Motivasi Kerja terhadap Kinerja Guru Produktif SMK Negeri 3 Kota Bima. Jurnal Manajemen Pendidikan Dan IImu Sosial, 1(2), 643-662. https://doi.org/10.38035/JMPIS.

Kridharta, D., \& Rusdianti, E. (2017). Analisis Pengaruh Karakteristik Individu, Komitmen Organisasi, dan Kepuasan Kerja terhadap Kinerja Karyawan dengan Motivasi sebagai Variabel Intervening. Jurnal Riset Ekonomi Dan Bisnis, 10(3), 232. https://doi.org/10.26623/jreb.v10i3.882.

Lengkong, V. P. K. (2018). Pengaruh Komitmen Organisasi dan Budaya Organisasi terhadap Kinerja Pegawai Di BKDPSDA Di Kabupaten Halmahera Utara. Jurnal EMBA: Jurnal Riset Ekonomi, Manajemen, Bisnis dan Akuntansi, 6(4), 1968-1977. https://doi.org/10.35794/emba.v6i4.20918.

Lestri, L. (2020). Pengaruh Komitmen Kerja, Motivasi Kerja, Stres Kerja, Lingkungan Kerja Non Fisik, dan Disiplin Kerja terhadap Kinerja Guru SMA Kartika I-5 Padang. 2020. http://repo.stkippgri-sumbar.ac.id/id/eprint/11988/.

Lina, R. (2020). Pengaruh Rekrutmen terhadap Kinerja Karyawan. Economic, Accounting, Management and Business, 3(3), 281-290. https://doi.org/10.37481/sjr.v3i3.223.

Mangkunegara, P. A. (2013). Manajemen Sumber Daya Manusia Perusahaan (Sebelas). PT Remaja Rosdakarya.

Ni Made Widnyani. (2020). Rekrutmen, Seleksi, dan Kinerja Karyawan. E-Jurnal Manajemen, 9(11), 3558 - 3579. https://doi.org/10.24843/EJMUNUD.2020.v09.i11.p07.

Octoriawan, A., \& Rusliati, E. (2019). Corporate Social Responsibility, Kepemilikan Manajerial terhadap Nilai Perusahaan dengan Moderasi Ukuran Perusahaan. Jurnal Riset Akuntansi Kontemporer, 11(2), 60-68. http://52.221.78.156/index.php/jrak/article/view/2771/1252.

Pratisardy, E., \& Lukito, H. (2019). Dampak Rekrutmen, Seleksi, dan Motivasi terhadap Kinerja Karyawan PT Bank XYZ TBK Cabang Padang. Jurnal Ekonomi Dan Bisnis, 21(1). https://doi.org/10.30811/ekonis.v21i1.896.

Pratiwi, W. A., Prasetyo, I., \& Shabrina, M. N. (2021). Faktor-Faktor yang Berpengaruh terhadap Kinerja Guru Taman Kanak-Kanak. 5(2), 1741-1753. https://doi.org/10.31004/obsesi.v5i2.970.

Rafiditya, A., \& Syarifuddin. (2020). Pengaruh Self Esteem dan Self Efficacy terhadap Kinerja Karyawan PT Dana Tabungan dan Asuransi Pegawai Negeri Kantor Cabang Utama Bandung. E-Procceding of Management, 7(2), 4143-4150.

Rangga, M., \& Naomi, P. (2017). Pengaruh Motivasi Diri terhadap Kinerja Belajar Mahasiswa. Jurnal Psikologi Paramadina, II, 1-8.

Syatoto, I. (2018). Pengaruh Rekrutmen dan Pelatihan terhadap Kinerja Karyawan Pada PT Radana Bhaskara Finance. Tbk. JENIUS (Jurnal IImiah Manajemen Sumber Daya Manusia), 1(2). https://doi.org/10.32493/JJSDM.v1i2.927.

Triasmoko, D., \& Mukzam, M. D. (2014). Penelitian pada Karyawan PT Pos Indonesia (Persero) Cabang Kota Kediri. Jurnal Administrasi Bisnis, 12(1), 1-10.

Wibowo, A. A. (2017). Komitmen dan Kompensasi terhadap Prestasi Kerja di PT Somit Karsa Trinergi Jakarta. Jurnal Ekonomi Dan Bisnis, 1(1), 1-19. https://doi.org/10.22236/agregat_vol1/is1pp1-19.

Wolomasi, A. K., Werang, B. R., \& Asmaningrum, H. P. (2019). Komitmen Kerja dan Pengaruhnya terhadap Semangat dan Kepuasan Kerja Guru Sekolah Dasar. Musamus Journal of Primary Education, 2(1), 13-23. https://doi.org/10.35724/musjpe.v2i1.1572. 